\title{
THE EVALUATION OF HIGH PROTEIN FOOD PROCESSING AS NUGGET IN PEKON TANJUNG JATI TANGGAMUS DISTRICT
}

\author{
Susanti ${ }^{1 *}$, Zukryandry ${ }^{2}$, Hertini Rani ${ }^{3}$ \\ ${ }^{1}$ Program Studi Produksi Ternak, Politeknik Negeri Lampung \\ ${ }^{2,3}$ Program Studi Teknologi Pangan, Politeknik Negeri Lampung \\ Email: susantisukses@polinela.ac.id
}

\begin{abstract}
The trend consumption foods of ready to cook and ready to eat is an alternative choice for the community and increasing public awareness about nutrition and health encourages people to live healthier lives by consuming nutritious foods and have a healthy effect. Processing nuggets production of the Tanjung Jati Women's Farmers Group is quite well received by consumers but the processing of this product is still done with simple technology. Improvements or technological touches need to be done so that the resulting nugget products have added value. The current problem causes the economic benefits that should have been obtained from this production activity can not be felt optimally. Community service is carried out in Tanjung Jati Pekon, Kota Agung Timur District, Tanggamus Regency. Activities in the form of counseling, socialization and practice of nugget product processing and packaging techniques are located at the Balai Rakyat Pekon Tanjung Jati, Kota Agung Timur District, Tanggamus District and the time to carry out activities in January 2020. The nugget training procedures include: a preliminary survey, counseling for the development of nugget product processing for Wanita Tani Pekom Tanjung Jati, socialization of the regulations of the head of the Indonesian drug and food regulatory body regarding packaging and labeling, technical guidance on processing and packaging of nuggets, and technical guidance on business plans and marketing of nuggets. The results of the activities showed the average value of the initial and final evaluation scores of the trainees was 34.77 and 82.50. If viewed from the increase in the score, it appears that an increase in score of 47.8 points. This shows that the training activities went quite well. The training activities were able to motivate the Tanjung Jati Pekon Women Farmers Group in Tanggamus Regency to develop the region's businesses. Advice from the training activities of making and packaging nuggets require further assistance to develop various local resource-based businesses..
\end{abstract}

Keywords : processing, nugget, food.

\section{Article Info:}

Received 22 Mei 2020

Accepted 01 Juni 2020

Available online 31 Agustus 2020

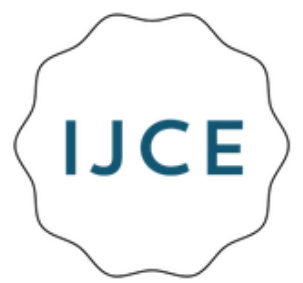




\begin{abstract}
Abstrak
Trend konsumsi dari makanan siap masak (ready to cook) dan siap makan (ready to eat) menjadi alternatif pilihan masyarakat dan peningkatan kesadaran masyarakat tentang gizi dan kesehatan mendorong masyarakat untuk hidup lebih sehat dengan mengkonsumsi makanan yang bergizi dan mempunyai efek menyehatkan.. Olahan nugget produksi Kelompok Wanita Tani Pekon Tanjung Jati cukup mendapat penerimaan baik oleh konsumen akan tetapi pengolahan produk ini masih dilakukan dengan teknologi sederhana. Perbaikan atau sentuhan teknologi perlu dilakukan sehingga produk nugget yang dihasilkan memiliki nilai tambah. Masalah yang ada saat ini menyebabkan keuntungan ekonomi yang seyogyanya diperoleh dari kegiatan produksi ini belum dapat dirasakan secara optimal. Pengabdian masyarakat dilaksanakan di Pekon Tanjung Jati Kecamatan Kota Agung Timur Kabupaten Tanggamus. Kegiatan berupa penyuluhan, sosialisasi dan praktek teknik pengolahan dan pengemasan produk nugget berlokasi di Balai Rakyat Pekon Tanjung Jati Kecamatan Kota Agung Timur Kabupaten Tanggamus dan waktu pelaksanaan kegiatan pada Bulan Januari 2020. Prosedur pelatihan nugget meliputi : survey pendahuluan, penyuluhan pengembangan pengolahan produk nugget bagi Wanita Tani Pekom Tanjung Jati, sosialisasi peraturan kepala badan pengawas obat dan makanan RI tentang pengemasan dan pelabelan, bimbingan teknis pengolahan dan pengemasan nugget,dan bimbingan teknis rencana bisnis dan pemasaran nugget. Hasil kegiatan menunjukkan nilai rata-rata skor evaluasi awal dan akhir peserta pelatihan adalah sebesar 34,77 dan 82,50. Jika ditinjau dari peningkatan skor tersebut, terlihat bahwa terjadi peningkatan skor sebesar 47.8 poin. Hal ini menunjukkan bahwa kegiatan pelatihan berjalan cukup baik. Kegiatan pelatihan mampu memotivasi Kelompok Wanita Tani Pekon Tanjung Jati di Kabupaten Tanggamus untuk mengembangkan usaha wilayah tersebut. Saran dari kegiatan pelatihan pembuatan dan pengemasan nugget diperlukan upaya pendampingan lebih lanjut untuk mengembangkan usaha aneka berbasis sumberdaya lokal.
\end{abstract}

Kata Kunci: Pengolahan, Nugget, Pangan 


\section{PENDAHULUAN}

Peningkatan kesadaran masyarakat tentang gizi dan kesehatan mendorong masyarakat untuk hidup lebih sehat dengan mengkonsumsi makanan yang bergizi. Trend konsumsi dari makanan siap masak (ready to cook) dan siap makan (ready to eat) menjadi alternatif pilihan masyarakat. Di sisi lain meningkatnya kesadaran masyarakat tentang gizi dan kesehatan mendorong masyarakat untuk hidup lebih sehat dengan mengkonsumsi makanan yang bergizi dan mempunyai efek menyehatkan. Kondisi ini harus disadari dan segera direspon oleh produsen, tidak terkecuali oleh industri nugget. Salah satu upaya untuk memenuhi keinginan konsumen adalah upaya pelatihan dan pengembangan produk nugget. Nugget merupakan salah satu produk pangan cepat saji yang saat ini dikenal baik oleh masyarakat. Nugget, seperti juga sosis, burger, dan corned, telah menjadi salah satu pilihan masyarakat sebagai produk pangan yang praktis. Nugget terbuat dari daging cincang yang telah dibumbui dan biasanya dibentuk menjadi bulat, stik atau bentuk lain. Produk nugget yang ada di pasaran biasanya berupa nugget ayam, nugget daging sapi, dan nugget ikan. Sampai saat ini produk nugget adalah salah satu produk yang cukup populer. Salah satu contoh UMKM yang sudah berjalan adalah Kelompok Wanita Tani Pekon Tanjung Jati yang bergerak dibidang olahan nugget. Kelompok Wanita Tani ini terletak di Pekon Tanjung Jati Kecamatan Kota Agung Timur Kabupaten Tanggamus. Olahan nugget produksi Kelompok Wanita Tani Pekon Tanjung Jati cukup mendapat penerimaan baik oleh konsumen akan tetapi pengolahan produk ini masih dilakukan dengan teknologi sederhana. Perbaikan atau sentuhan teknologi perlu dilakukan sehingga produk nugget yang dihasilkan memiliki potensi lebih baik untuk diaplikasikan oleh masyarakat pedesaan, terutama kelompok wanita tani (KWT) sebagai suatu bentuk UMKM. Ibu-ibu rumah tangga yang bergabung dalam kelompok Kelompok Wanita Tani Pekon Tanjung Jati memiliki inisiatif mengembangkan usaha setelah mendapat pelatihan dari tim pengabdian masyarakat Politeknik Negeri Lampung. Produksi nugget telah dilakukan oleh Kelompok Wanita Tani Pekon Tanjung Jati sejak tahun 2019. Produk ini berpotensi diusahakan dengan alasan pertama yaitu ketersediaan bahan baku utama. Potensi kedua, yaitu adanya konsumen tetap dan produk ini memiliki keunggulan yaitu harga yang terjangkau, tanpa bahan pengawet kimia makanan dan tahan lama. Selama kurang lebih 3 bulan usaha nugget yang dijalankan ini belum menunjukkan perkembangan dan dampak ekonomi yang signifikan terhadap kemajuan usahanya. Hal ini dapat dilihat dari masih terbatasnya wilayah distribusi yang hanya meliputi kecamatan Kota Agung Timur dan sekitarnya. Kesulitan untuk memasarkan produk nugget juga karena persaingan antara UMKM yang membuat persaingan semakin ketat dalam memperebutkan pasar.

Masalah yang ada saat ini menyebabkan keuntungan ekonomi yang seyogyanya diperoleh dari kegiatan produksi ini belum dapat dirasakan secara optimal. Aktifitas pemasaran yang belum optimal dilakukan mengakibatkan volume penjualan produk nugget masih rendah. Oleh karena itu, diperlukan pelatihan pembuatan dan pengembangan serta strategi pemasaran untuk dapat meningkatkan kinerja pemasaran yang dihadapi oleh Kelompok Wanita Tani Pekon Tanjung Jati. Berdasarkan analisa situasi beberapa permasalahan yang teridentifikasi sebagai berikut :

1. Sangat terbatasnya pasar produk nugget

2. Harga jual yang rendah

3. Keuntungan yang diperoleh dalam memproduksi produk nugget sangat kecil, hanya cukup menutupi ongkos produksi.

4. Terbatasnya pengetahuan anggota Kelompok Wanita Tani Pekon Tanjung Jati dalam pengembangan usaha.

5. Masyarakat belum pernah mendapatkan pengetahuan dan keterampilan terkait pengolahan pangan yang baik. 
6. Terbatasnya pengetahuan anggota Kelompok Wanita Tani Pekon Tanjung Jati dalam memasarkan produk hilir produk nugget.

7. Terbatasnya pengetahuan anggota Kelompok Wanita Tani Pekon Tanjung Jati dalam perencanaan pengembangan bisnis

8. Terbatasnya pengetahuan anggota Kelompok Wanita Tani Pekon Tanjung Jati dalam mengembangkan bisnis.

\subsection{Tujuan pengabdian masyarakat ini adalah:}

1. Memberikan pemahaman dan pengetahuan kepada masyarakat khususnya Kelompok Wanita Tani Pekon Tanjung Jati, Kabupaten Tanggamus tentang pengembangan usaha

2. Mendemontrasikan teknik pengolahan produk nugget

3. Memberikan pemahanan persyaratan pengemasan melalui sosialisasi Peraturan Kepala Badan Pengawas Obat dan Makanan Republik Indonesia

\subsection{Kegiatan pengabdian masyarakat ini bermanfaat bagi :}

1. Masyarakat untuk meningkatkan pemahaman tentang pengembangan usaha, cara pengolahan produk dan cara pengemasan produk, memahami teknik pengemasan, memahami persyaratan pengemasan sesuai Peraturan Kepala Badan Pengawas Obat dan Makanan Republik Indonesia dan meningkatkan pemahaman masyarakat rencana pengemasan dan pemasaran produk.

2. Politeknik Negeri Lampung, guna mengaplikasikan penelitian yang telah dilaksanakan oleh pendidikan tinggi menjadi hal yang bermanfaat di masyarakat

3. Pemerintah Provinsi Lampung khususnya Kabupaten Tanggamus guna mengembangkan dan meningkatkan nilai tambah produk nugget

\subsection{Luaran dan Rencana Luaran Kegiatan:}

Adapun luaran dari kegiatan pengabdian ini adalah :

1. Lebih dari $70 \%$ anggota kelompok Kelompok Wanita Tani Pekon Tanjung Jati, mengetahui dan memahami tentang pengolahan dan pengembangan usaha nugget

2. Lebih dari $70 \%$ anggota kelompok Kelompok Wanita Tani Pekon Tanjung Jati, mengetahui dan memahami tentang pengemasan dan pelabelan produk nugget

3. Lebih dari $70 \%$ anggota Kelompok Wanita Tani Pekon Tanjung Jati mampu memahami teknis pengembangan bisnis dan pemasaran produk nugget

Jenis luaran yang ingin dicapai dari kegiatan ini adalah produk nugget dengan 3 varian kemasan: plastik biasa, plastik vakum dan plastik kemasan jumbo. Komposisi produk nugget yang akan dihasilkan merupakan bahan-bahan alami antara lain: daging giling, maizena, tepung roti, minyak goring dan bumbu. Capaian luaran yang dihasilkan dari kegiatan ini adalah sebagaimana tertera pada Tabel 1 .

Tabel 1. Capaian Luaran

\begin{tabular}{c|lc}
\hline No & \multicolumn{1}{|c}{ Jenis Luaran } & $\begin{array}{c}\text { Indikator } \\
\text { Capaian }\end{array}$ \\
\hline 1 & $\begin{array}{l}\text { Peningkatan omzet pada mitra yang bergerak dalam } \\
\text { bidang ekonomi }\end{array}$ & Ada \\
2 & Peningkatan kuantitas dan kualitas produk & Ada \\
3 & Peningkatan pemahaman dan keterampilan masyarakat & Ada \\
4 & Peningkatan ketentraman/kesehatan masyarakat & Ada \\
\hline
\end{tabular}




\section{METODE}

Pengabdian masyarakat dilaksanakan di Pekon Tanjung Jati Kecamatan Kota Agung Timur Kabupaten Tanggamus. Rencana kegiatan berupa penyuluhan, sosialisasi dan praktek teknik pengolahan dan pengemasan produk nugget berlokasi di Balai Rakyat Pekon Tanjung Jati Kecamatan Kota Agung Timur Kabupaten Tanggamus dan waktu pelaksanaan kegiatan pada Bulan Januari 2020.

Pengabdian ini dilakukan dengan metode penyuluhan, sosialisasi, diskusi serta pelatihan teknis. Berdasarkan prioritas permasalahan diusulkan beberapa solusi yang tertuang dalam kegiatan dengan justifikasi sebagai berikut :

1. Kegiatan penyuluhan tentang pengolahan dan pengembangan produk nugget dan manfaat lainnya. Kegiatan ini penting karena pemahaman masyarakat yang rendah dan guna membuka wawasan dan pengetahuan tentang pengolahan dan pengembangan produk nugget dan manfaat yang dimiliki pengolahan dan pengembangan produk nugget. Serta membuka wawasan peserta bahwa pengolahan dan pengembangan produk nugget tersebut dapat dilakukan oleh Kelompok Wanita Tani Pekon Tanjung Jati.

2. Kegiatan sosialisasi Peraturan Kepala Badan Pengawas Obat dan Makanan Republik Indonesia tentang Persyaratan pengemasan dan pelabelan. Masyarakat belum pernah mendapatkan pengetahuan terkait persyaratan dan pelabelan. Sosialisasi ini bertujuan untuk memberikan pemahaman tentang persyaratan pengemasan dan pelabelan yang perlu dipenuhi suatu produk olahan pangan.

Kegiatan bimbingan teknis rencana bisnis dan pemasaran produk nugget. Kegiatan ini dibutuhkan untuk memberikan cara-cara yang dapat digunakan oleh Kelompok Wanita Tani Pekon Tanjung Jati dalam merencanakan bisnis dan memasarkan produk nugget yang dihasilkan. Berdasarkan permasalahan yang ada di lapangan dipilih metode peyuluhan sosialisasi dan pelatihan teknis serta diskusi. Pemecahan masalah distrukturkan dalam kerangka sesuai Tabel 2 berikut ini:

Tabel 2. Rumusan Kerangka Pemecahan Masalah

\begin{tabular}{|c|c|c|c|}
\hline No & Situasi Saat Ini & Perlakuan & Situasi Yang Diharapkan \\
\hline 1 & $\begin{array}{l}\text { Masyarakat } \\
\text { memiliki keterbatasan } \\
\text { pengetahuan dan } \\
\text { teknologi pengolahan } \\
\text { dan pengembangan } \\
\text { produk nugget }\end{array}$ & $\begin{array}{l}\text { Dilaksanakan } \\
\text { penyuluhan tentang } \\
\text { cara pengolahan } \\
\text { dan pengembangan } \\
\text { produk nugget }\end{array}$ & $\begin{array}{l}\text { Lebih dari } 70 \% \text { anggota } \\
\text { kelompok wanita tani } \\
\text { memahami manfaat dan } \\
\text { pengetahuan tentang } \\
\text { pengolahan dan } \\
\text { pengembangan produk }\end{array}$ \\
\hline 2 & $\begin{array}{l}\text { Masyarakat belum } \\
\text { memahami dan belum } \\
\text { pernah mendapatkan } \\
\text { teknis rencana bisnis } \\
\text { dan pemasaran produk }\end{array}$ & $\begin{array}{l}\text { Dilaksanakan } \\
\text { bimbingan teknis } \\
\text { rencana bisnis dan } \\
\text { pemasaran produk } \\
\text { nugget }\end{array}$ & $\begin{array}{l}\text { Lebih dari } 70 \% \text { anggota } \\
\text { Kelompok Wanita Tani } \\
\text { Pekon Tanjung Jati } \\
\text { memahami rencana } \\
\text { bisnis dan pemasaran }\end{array}$ \\
\hline
\end{tabular}


Prosedur kerja kegiatan pengabdian "Pelatihan Teknis Pembuatan Nugget Sebagai Produk Pangan Tinggi Protein di Pekon Tanjung Jati Kabupaten Tanggamus", meliputi:

1. Survey pendahuluan,

2. Penyuluhan pengembangan pengolahan produk nugget bagi Wanita Tani Pekom Tanjung Jati,

3. Sosialisasi peraturan kepala badan pengawas obat dan makanan RI tentang pengemasan dan pelabelan,

4. Bimbingan teknis pengolahan dan pengemasan nugget,

5. Bimbingan teknis rencana bisnis dan pemasaran nugget.

\section{HASIL DAN PEMBAHASAN}

1. Materi Evaluasi

Kegiatan evaluasi dilakukan untuk mengetahui efektifitas pelaksanaan kegiatan pelatihan. Evaluasi awal dilakukan sebelum pemberian materi pelatihan dalam bentuk ceramah (sesi pertama), sedangkan evaluasi akhir dilakukan setelah sesi evaluasi praktik mandiri (sesi terakhir).

2. Hasil Evaluasi

Hasil evaluasi kegiatan pelatihan, disajikan pada Tabel 3 berikut.

Tabel 3. Rekapitulasi Hasil Evaluasi Pelatihan

\begin{tabular}{|c|c|c|c|c|}
\hline \multirow[t]{2}{*}{ No } & \multirow[t]{2}{*}{ Nomor Peserta } & \multicolumn{2}{|c|}{ Hasil Evaluasi } & \multirow[t]{2}{*}{ Keterangan } \\
\hline & & Awal & Akhir & \\
\hline 1 & 1 & 10 & 60 & Peningkatan skor 50 \\
\hline 2 & 2 & 40 & 80 & Peningkatan skor 40 \\
\hline 3 & 3 & 40 & 80 & Peningkatan skor 40 \\
\hline 4 & 4 & 20 & 90 & Peningkatan skor 70 \\
\hline 5 & 5 & 20 & 90 & Peningkatan skor 70 \\
\hline 6 & 6 & 40 & 80 & Peningkatan skor 40 \\
\hline 7 & 7 & 20 & 70 & Peningkatan skor 50 \\
\hline 8 & 8 & 50 & 90 & Peningkatan skor 40 \\
\hline 9 & 9 & 60 & 80 & Peningkatan skor 20 \\
\hline 10 & 10 & 20 & 80 & Peningkatan skor 60 \\
\hline 11 & 11 & 20 & 80 & Peningkatan skor 60 \\
\hline 12 & 12 & 50 & 80 & Peningkatan skor 30 \\
\hline 13 & 13 & 50 & 90 & Peningkatan skor 40 \\
\hline 14 & 14 & 40 & 90 & Peningkatan skor 50 \\
\hline 15 & 15 & 30 & 80 & Peningkatan skor 50 \\
\hline 16 & 16 & 40 & 100 & Peningkatan skor 60 \\
\hline 17 & 17 & 30 & 100 & Peningkatan skor 70 \\
\hline 18 & 18 & 50 & 70 & Peningkatan skor 20 \\
\hline 19 & 19 & 50 & 80 & Peningkatan skor 30 \\
\hline 20 & 20 & 10 & 80 & Peningkatan skor 50 \\
\hline 21 & 21 & 10 & 60 & Peningkatan skor 50 \\
\hline
\end{tabular}




\begin{tabular}{|c|c|c|c|c|}
\hline \multirow[t]{2}{*}{ No } & \multirow[t]{2}{*}{ Nomor Peserta } & \multicolumn{2}{|c|}{ Hasil Evaluasi } & \multirow[t]{2}{*}{ Keterangan } \\
\hline & & Awal & Akhir & \\
\hline 22 & 22 & 40 & 80 & Peningkatan Skor 40 \\
\hline 23 & 1 & 10 & 60 & Peningkatan skor 50 \\
\hline 24 & 2 & 40 & 80 & Peningkatan skor 40 \\
\hline 25 & 3 & 40 & 80 & Peningkatan skor 40 \\
\hline 26 & 4 & 20 & 90 & Peningkatan skor 70 \\
\hline 27 & 5 & 20 & 90 & Peningkatan skor 70 \\
\hline 28 & 6 & 40 & 80 & Peningkatan skor 40 \\
\hline 29 & 7 & 20 & 70 & Peningkatan skor 50 \\
\hline 30 & 8 & 50 & 90 & Peningkatan skor 40 \\
\hline 31 & 9 & 60 & 80 & Peningkatan skor 20 \\
\hline 32 & 10 & 20 & 80 & Peningkatan skor 60 \\
\hline 33 & 11 & 20 & 80 & Peningkatan skor 60 \\
\hline 34 & 12 & 50 & 80 & Peningkatan skor 30 \\
\hline 35 & 13 & 50 & 90 & Peningkatan skor 40 \\
\hline 35 & 14 & 40 & 90 & Peningkatan skor 50 \\
\hline 37 & 15 & 30 & 80 & Peningkatan skor 50 \\
\hline 38 & 16 & 40 & 100 & Peningkatan skor 60 \\
\hline 39 & 17 & 30 & 100 & Peningkatan skor 70 \\
\hline 40 & 18 & 50 & 70 & Peningkatan skor 20 \\
\hline 41 & 19 & 50 & 80 & Peningkatan skor 30 \\
\hline 42 & 20 & 10 & 80 & Peningkatan skor 50 \\
\hline \multirow[t]{2}{*}{43} & 20 & 10 & 80 & Peningkatan skor 50 \\
\hline & Rata-rata & 34,77 & 82,50 & Peningkatan skor $\mathbf{4 7 , 8}$ \\
\hline
\end{tabular}

Pada Tabel 3, terlihat bahwa nilai rata-rata skor evaluasi awal dan akhir peserta pelatihan adalah sebesar 34,77 dan 82,50. Jika ditinjau dari peningkatan skor tersebut, terlihat bahwa terjadi peningkatan skor sebesar 47.8 poin. Hal ini menunjukkan bahwa kegiatan pelatihan berjalan cukup baik. Berdasarkan Tabel 4, juga terlihat bahwa sebelum kegiatan pelatihan rata-rata skor sebesar 34,50 dan hanya 2 peserta (5\%) yang memiliki skor di atas 50. Skor 34,50 ini menunjukkan bahwa pemahaman peserta tentang aspek-aspek pengolahan aneka produk pangan berbasis sumberdaya lokal relatif rendah. Setelah kegiatan pelatihan rata-rata skor sebesar 82,50 , dengan rincian hampir seluruh peserta memiliki skor $\geq 60$. Hal ini juga menunjukkan bahwa materi kegiatan pelatihan mampu diserap baik oleh peserta.

\section{KESIMPULAN dan SARAN}

Dalam kegiatan bimbingan pelatihan pembuatan dan pengemasan nugget diperlukan kegiatan pembimbingan lebih lanjut untuk mengembangkan usaha lokal bagi Kelompok Wanita Tani Pekon Tanjung Jati. Kegiatan pelatihan mampu memotivasi Kelompok Wanita Tani Pekon Tanjung Jati di Kabupaten Tanggamus untuk mengembangkan usaha wilayah tersebut. Saran dari kegiatan pelatihan pembuatan dan pengemasan nugget diperlukan upaya pendampingan 
lebih lanjut untuk mengembangkan usaha aneka berbasis sumberdaya lokal bagi Kelompok Wanita Tani Pekon Tanjung Jati di Kabupaten Tanggamus agar berkembang menjadi usaha yang produktif.

\section{REFERENSI}

[1] Badan Standarisasi Nasional. 2002. SNI. 01-6683. Nugget Ayam. Badan Standarisasi Nasional, Jakarta.

[2] Fellows, J. P. 2000. Food Processing Technology : Principles and Practise. 2nd Ed. Woodhead Publ, Lim. England, Cambridge.

[3] Jay, J. M. 2000. Modern Food Microbiology. 6th Ed. Aspen Publishers, Inc. Gaithersburg.

[4] Ketaren, S. 1986. Pengantar Teknologi Minyak dan Lemak Pangan. UI-Press. Jakarta.

[5] Owens, C. M. 2001. Coated Poultry Products. Didalam: Sam, A. R. Poultry Meat Processing. CRC Press. London. 